\title{
OČUVANJE OKOLIŠA I PRAKSA ZBRINJAVANJA OTPADA PREMA MIŠLJENJU UČENIKA MLAĐE ŠKOLSKE DOBI GRADA ZAGREBA
}

\author{
PRESERVATION OF THE ENVIRONMENT AND WASTE \\ MANAGEMENT PRACTICES IN THE OPINION OF JUNIOR \\ PRIMARY SCHOOL STUDENTS IN THE CITY OF ZAGREB
}

\section{Božica Lukšić, K. Bošnjak, Ivana Čačić, Marina Vranić}

\section{SAŽETAK}

S gospodarskim rastom i razvojem povećava se kvaliteta života, ali time paralelno rastu i količine otpada u domaćinstvu. Gospodarenje otpadom danas predstavlja jedan od najvećih izazova modernog društva.

Za razvrstavanje i recikliranje kućnog i industrijskog otpada, potrebno je neprekidno obrazovanje na svim razinama.

Cilj ovog istraživanja bio je utvrditi razinu teoretskog znanja o zbrinjavanju otpada iz domaćinstva te primjenu ekoloških principa očuvanja okoliša u svakodnevnom životu učenika mlađe školske dobi osnovnih škola Grada Zagreba.

Istraživanje je provedeno u okviru edukativnih radionica „Upoznajmo domaće životinje“ na pokušalištu Centar za travnjaštvo Sveučilišta u Zagrebu Agronomskog fakulteta, tijekom školske godine 2017/18. Istraživanje je provedeno metodom ankete $\mathrm{u}$ kojoj je sudjelovalo ukupno 497 učenika, od kojih 241 djevojčica i 256 dječaka.

Rezultati istraživanja ukazuju na dobro poznavanje načina zbrinjavanja otpada iz domaćinstva, spremnost na očuvanje okoliša i prirodnih resursa te dobre životne navike u svakodnevnom životu učenika mlađe školske dobi osnovnih škola Grada Zagreba, usmjerene očuvanju okoliša. Zaključeno je da jedino neprekidan i zajednički rad odgojno-obrazovnog sustava i kućnog odgoja podiže ekološku svijest te pomaže izgradnji pozitivnog stava djece prema očuvanju okoliša.

Ključne riječi: zbrinjavanje otpada, osnovne škole Grada Zagreba, učenici mlađe školske dobi 
Božica Lukšić i sur.: Očuvanje okoliša i praksa zbrinjavanja otpada prema mišljenju učenika mlađe školske dobi Grada Zagreba

\begin{abstract}
The economic growth and development increases the quality of life but in parallel the amount of household waste produced. Waste management is one of the greatest challenges of modern society.

The aim of this study was to determine the level of theoretical knowledge on household waste disposal and the application of environmental principles in everyday life of junior primary school students in the City of Zagreb.
\end{abstract}

The research was carried out within the Educational Workshops "Let's meet the domestic animals" at the Grassland Research Center of the University of Zagreb Faculty of Agriculture during the school year 2017/18. The survey involved a total of 497 junior primary school students, out of which 241 girls and 256 boys.

The results show the junior primary school students in the City of Zagreb have a high level of knowledge in a household waste disposal. They also have good living habits in terms of hausehold waste management and potential contribution towards environmental conservation.

To accept the classification and recycling of household and industrial waste, continuous at home and at school education and training is required at all the levels of education.

Key words: waste disposal, primary schools of the City of Zagreb, junior primary school students

\title{
UVOD
}

Gospodarenje komunalnim otpadom danas predstavlja jedan od najvećih ekoloških problema modernog društva. Sukladno Zakonu o održivom gospodarenju otpadom u Republici Hrvatskoj (NN 94/2013, članak 4.), „otpad““ je svaka tvar ili predmet koji posjednik odbacuje, namjerava ili mora odbaciti. Otpadom se smatra i svaki predmet i tvar čije su sakupljanje, prijevoz i obrada nužni u svrhu zaštite javnog interesa. U cilju primjene propisa i politike gospodarenja otpadom važno je primjenjivati red prvenstva gospodarenja otpadom, sprječavanje njegova nastajanja, pripremu za ponovnu uporabu, recikliranje i zbrinjavanje (NN 94/2013, članak 7.). 
Božica Lukšić i sur.: Očuvanje okoliša i praksa zbrinjavanja otpada prema mišljenju učenika mlađe školske dobi Grada Zagreba

Riječ recikliranje potječe iz engleskog jezika (recycle), što znači ponovno kruženje. U kontekstu komunalnog otpada, recikliranje je svaki postupak ponovne prerade organskog materijala, kojim se otpadni materijali prerađuju u proizvode, materijale ili tvari za izvornu ili drugu svrhu osim uporabe otpada u energetske svrhe, odnosno prerade u materijal koji se koristi kao gorivo (NN 94/2013, članak 4.). „Oporaba otpada“ je svaki postupak čiji je glavni rezultat upotreba otpada u korisne svrhe kada otpad zamjenjuje druge materijale koje bi inače trebalo uporabiti za tu svrhu ili otpad koji se priprema kako bi ispunio tu svrhu, u tvornici ili u širem gospodarskom smislu (NN 94/2013, članak 4.). Reciklirati se može oko $90 \%$ otpada pa su u tu svrhu u RH postavljeni Zeleni otoci na mjestima sakupljanja. To su jasno označena i lako dostupna mjesta, obično na javnim površinama, s nekoliko namjenskih spremnika u koje se odlažu pojedine sastavnice komunalnog otpada (papir, karton, staklo, plastika, tekstil, biootpad).

Razvrstavanje i recikliranje kućnog i industrijskog otpada nije „proizvod“ suvremenog čovjeka, nego su i kroz povijest ljudi pokazivali pozitivan stav prema okolišu ponovnom upotrebom otpada kao sekundarne sirovine. O gospodarenju otpadom potrebno je neprekidno obrazovanje jer ekološki odgoj i obrazovanje, kao i odgoj za zaštitu i očuvanje čovjekova okoliša, nije konačno stanje koje se svim navedenim aktivnostima može postići tijekom osnovnog i srednjoškolskog obrazovanja, nego je to način života u koji se neprestano uključuju nove životne situacije koje treba postupno rješavati u skladu $\mathrm{s}$ ekološkim normama i na razini zapadne civilizacije (Pavičić, 1993.).

Grodzinska-Jurczak (2003.) navodi da pozitivan pristup okolišu treba biti potaknut odgojno-obrazovnim aktivnostima u školskom sustavu jer jedino neprekidno obrazovanje društva može podići razinu ekološke osvještenosti.

Kroz niz publikacija i događanja (1980. World Conservation Strategy; 1987. WCED izvješće "Our Common Future"; konferencija UN-a o okolišu 1992. u Riu i dr.), intenzivno se propagira potreba ekološkog odgoja i obrazovanja (Clifton, 2009.) s čim u svezi je porastao i broj istraživanja utjecaja čovjeka na okoliš (Palmer i Birch, 2005.). Ranija istraživanja Europske zajednice upozoravaju da je problem zagađenja Zemlje, za većinu stanovništva zapadnog svijeta, veći od problema inflacije, siromaštva i nezaposlenosti (Spajić-Vrkaš, 1993.). U istraživanju poznavanja gospodarenja otpadom djece različite dobi (4 i 6 godina) provedenom u Velikoj Britaniji i Sjedinjenim Američkim Državama zaključeno je da su mlađa djeca pokazala veći stupanj nesigurnosti ili nedostatka znanja od starije (Palmer, 1995.), a što potvrđuje utjecaj dobi na razvoj svijesti i poznavanje problematike gospodarenja otpadom. 
Božica Lukšić i sur.: Očuvanje okoliša i praksa zbrinjavanja otpada prema mišljenju učenika mlađe školske dobi Grada Zagreba

Osim dobi, na poznavanje gospodarenja otpadom utječe i država svojim razvojem i provedbom obrazovnih programa. U istraživanju poznavanja gospodarenja otpadom u koje su bila uključena djeca osnovnih škola u Velikoj Britaniji, Sloveniji i Grčkoj $(n=527)$ utvrđeno je bolje poznavanje gospodarenja otpadom učenika osnovnih škola u Velikoj Britaniji i Sloveniji u usporedbi s Grčkom, dok su djeca osnovnih škola iz Grčke imala znatno više znanja o procesu recikliranja otpada od djece u Sloveniji (Palmer, 1995.).

Poznavanjem trenutnog stanja onečišćenja planeta Zemlje te mogućih uzroka onečišćenja, djeca razvijaju globalnu sliku budućnosti planeta Zemlje. U istraživanje projekcije planeta Zemlje za 50 godina s obzirom na onečišćenje, globalno zatopljenje, nedostatak vode, kisele kiše i nestajanje vrsta u koje su bila uključena djeca u dobi od 7 i 9 godina iz Meksika i Engleske $(\mathrm{n}=741)$, Barraz (1999.) navodi da 54\% djece za 50 godina vidi Zemlju u lošijem stanju, $22 \%$ djece drži da će doći do poboljšanja, a preostalih $18 \%$ da neće doći do nikakvih promjena.

Okolina odrastanja (selo-grad) također može razvijati senzibilitet prema prirodi. Wells i Lekies (2006.) su u SAD-u istražili odnos prema prirodi oko 2000 ispitanika u dobi od 18. do 90. godine života obzirom na njihova iskustva iz djetinjstva, trenutne stavove i način života te zaključili da djetinjstvo provedeno u bližem kontaktu s prirodom može značajnije usmjeriti čovjeka na zaštitu okoliša i razviti cijeloživotni interes za okoliš.

Davis (1998.) navodi da je kvalitetno obrazovanje o zaštiti okoliša u ranom djetinjstvu poticajno te može doprinijeti velikim promjenama za bolju budućnost i održivost mjesta u kojem živimo.

Ekološki odgoj i obrazovanje trebalo bi postaviti kao nastavno načelo sveukupne nastave, kao princip koji se više ili manje provodi kroz gotovo sve nastavne predmete te izvannastavne i izvanškolske aktivnosti (Pavičić, 1993.) na koji se način u RH samo djelomično provode nastavni sadržaji o ekologiji i zaštiti okoliša.

Danas u RH, aktivan status Eko-škole imaju 334 odgojno-obrazovne ustanove, od toga 89 dječjih vrtića, 195 osnovnih škola, 7 centara za odgoj i obrazovanje, 38 srednjih škola, dva učenička doma i tri visoko-obrazovne institucije. Glavni cilj programa Eko-škola je da se obrazovanje i odgoj o okolišu ugradi u sve segmente odgojno-obrazovnog sustava, a i u svakodnevni život učenika i djelatnika. Posebna pozornost je posvećena smanjenju i zbrinjavanju otpada te racionalnijem korištenju prirodnih resursa, prvenstveno vode $\mathrm{i}$ energije. 
Božica Lukšić i sur.: Očuvanje okoliša i praksa zbrinjavanja otpada prema mišljenju učenika mlađe školske dobi Grada Zagreba

Novoselić i sur. (2013.) su utvrdili izuzetno slabu zastupljenost ekoloških tema u udžbenicima osnovnih škola iz predmeta Priroda i društvo u RH. Autori navode da program nije mjerodavan sa zahtjevima koje suvremeno društvo stavlja pred školu te zaključuju da je potrebno povećati broj ekoloških tema kako bi učenici bili uspješniji u učenju i izgradnji pozitivnih stavova prema prirodi.

U istraživanju socijalnih i ekoloških aspekata problema otpada te praksa recikliranja u kojem su sudjelovali studenti Filozofskog fakulteta u Splitu (Stanić i Buzov, 2009.) utvrđeno je da su studenti osjetljivi prema problemu otpada, neke vrste otpada recikliraju više u odnosu na druge, a većina studenata je spremna sudjelovati u ponuđenim aktivnostima vezanim za problem nastanka i zbrinjavanja otpada.

U usporedbi rezultata istraživanja (Stanić i Buzov, 2009.) s rezultatima istraživanja odnosa prema otpadu stanovništva Grada Splita (Stanić i sur., 2009.), zaključeno je da su studenti ekološki osvješteniji. Nadalje, studenti su spremniji ekološki djelovati te u većoj mjeri recikliraju stari papir bez motiva zarade kroz sustav otkupa, dok stanovnici Grada Splita u većoj mjeri zbrinjavaju ambalažni otpad koji je uključen u sustav otkupa nego druge vrste otpada koje nisu uključene u sustav otkupa. Zaključeno je da postoji svijest u svezi s recikliranjem, s obzirom na važnost problema otpada i njegovu eskalaciju, uz krizu resursa i energije te da će recikliranje u budućnosti postati obvezni dio svakodnevice svakog pojedinca. U istraživanju Stanića i Buzova (2009.) 78\% studenata Filozofskog fakulteta u Splitu smatra da je potrebno uvođenje ekološkog obrazovanja u škole, a njih $83 \%$ da je potrebno obrazovanje odraslih iz područja ekologije i zaštite okoliša.

Hipoteza istraživanja bila je da učenici mlađe školske dobi osnovnih škola Grada Zagreba imaju dobro teoretsko znanje o zbrinjavanju otpada iz domaćinstva i primjenu osnovnih ekoloških principa u svakodnevnom životu. Cilj istraživanja bio je utvrditi razinu teoretskog znanja o zbrinjavanju otpada iz domaćinstva te primjenu ekoloških principa očuvanja okoliša u svakodnevnom životu, učenika od 1. do 3. razreda osnovnih škola Grada Zagreba. 
Božica Lukšić i sur.: Očuvanje okoliša i praksa zbrinjavanja otpada prema mišljenju učenika mlađe školske dobi Grada Zagreba

\section{MATERIJALI I METODE ISTRAŽIVANJA}

Istraživanje je provedeno tijekom 2017/18. školske godine u sklopu obrazovnih radionica „Upoznajmo domaće životinje“ na pokušalištu Centar za travnjaštvo Sveučilišta u Zagrebu Agronomskog fakulteta. Pokušalište se nalazi $\mathrm{u}$ parku prirode Medvednica. Program, proveden u obliku izvanučioničke nastave za djecu predškolske i osnovnoškolske dobi, je obuhvaćao teme zdrave prehrane, radionice u laboratoriju, radionice u stajama i na pašnjacima, šetnju poučnom šumskom stazom te predavanje o domaćim životinjama u sklopu kojeg se obrađuje i po jedna ekološka tema.

U istraživanju je sudjelovalo 497 učenika osnovnih škola Grada Zagreba, od kojih 241 djevojčica i 256 dječaka. Sudjelovali su učenici prvih (195 učenika), drugih (180 učenika) i trećih (122 učenika) razreda osnovnih škola. Istraživanje je provedeno metodom ankete koja je sadržavala ukupno 12 pitanja zatvorenog tipa.

U prvom dijelu ankete istraživano je u kojoj mjeri učenici poznaju boje spremnika za otpad s obzirom za vrstu otpada za koji su namijenjeni. U drugom dijelu ankete istraživane su životne navike učenika o razvrstavanju i odlaganju otpada $\mathrm{u}$ za to namijenjene spremnike. $U$ trećem dijelu ankete istraživan je utjecaj ispitanika na očuvanje planeta Zemlja s obzirom na štednju energije i prirodnih resursa.

\section{REZULTATI I RASPRAVA}

U prva tri pitanja ankete, istraživano je prepoznaju li učenici boju spremnika za odlaganje pojedinih vrsta otpada, a ponuđeni odgovori su bili: a) plave boje, b) žute boje, c) zelene boje, d) crvene boje.

Prvo pitanje je glasilo: „Koje boje je spremnik za odlaganje plastike?“. $\mathrm{Na}$ pitanje je točno odgovorilo $75 \%$ učenika (žute boje), $11 \%$ učenika je navelo da je plave boje, $12 \%$ da je zelene boje, a $2 \%$ učenika je odgovorilo da je spremnik za odlaganje plastike crvene boje (tablica 1.). 
Božica Lukšić i sur.: Očuvanje okoliša i praksa zbrinjavanja otpada prema mišljenju učenika mlađe školske dobi Grada Zagreba

Tablica 1. Prikaz odgovora učenika na pitanje „Koje boje je spremnik za odlaganje plastike?“"

Table 1 Students' answers to the question "What color is the container for plastic disposal?"

\begin{tabular}{|c|c|c|c|c|c|c|c|c|c|}
\hline \multirow{4}{*}{$\begin{array}{l}\text { Odgovori } \\
\text { Answers }\end{array}$} & \multicolumn{6}{|c|}{ Razred/Class } & \multirow{2}{*}{\multicolumn{2}{|c|}{ Ukupno/Total }} & \multirow{3}{*}{$\begin{array}{c}\text { Sveukupno/ } \\
\text { Total }\end{array}$} \\
\hline & \multicolumn{2}{|c|}{ Prvi /First } & \multicolumn{2}{|c|}{ Drugi/Second } & \multicolumn{2}{|c|}{ Treći/Third } & & & \\
\hline & 우 & 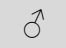 & 우 & $\sigma^{\pi}$ & 우 & $\hat{\sigma}$ & 우 & $\hat{\sigma}$ & \\
\hline & & & & & & & & & \\
\hline Plava/Blue & 11,3 & 6,6 & 14,8 & 20,9 & 6 & 5,7 & 11,7 & 10,8 & 11 \\
\hline Žuta/Yellow & 71,9 & 83,9 & 64,4 & 59,3 & 88 & 84,3 & 71,9 & 76,4 & 75 \\
\hline Zelena/Green & 14,6 & 9,5 & 16,9 & 17,3 & 6 & 10 & 13,8 & 12,1 & 12 \\
\hline Crvena/Red & 2,2 & 0 & 3,9 & 2,5 & 0 & 0 & 2,6 & 0,7 & 2 \\
\hline
\end{tabular}

+ , djevojčice/girls; $\widehat{\jmath}$, dječaci/boys

Iz tablice 1. je vidljivo da su učenici 3. razreda ponudili najviše točnih odgovora na pitanje „Koje boje je spremnik za odlaganje plastike?“. Djevojčice, učenice 3. razreda su imale najviši postotak točnih odgovora (88\%). Gledajući ukupan broj točnih odgovora, zaključuje se da dječaci imaju bolje znanje od djevojčica. Također, učenici 1. razreda dobro poznaju boje spremnika za odlaganje otpada, a mogući razlog je ekološki odgoj i obrazovanje djece predškolske dobi.

$\mathrm{Na}$ drugo pitanje „Koje je boje spremnik za odlaganje stakla?“, točan je odgovor dalo $74 \%$ učenika (zelene boje), da je spremnik plave boje je odgovorilo $11 \%$, da je žute boje također $11 \%$ i da je crvene boje $4 \%$ učenika (tablica 2 .).

Tablica 2. Prikaz odgovora učenika na pitanje: „Koje boje je spremnik za odlaganje stakla?"“

Table 2 Students' answers to the question "What color is the container for glass disposal?"

\begin{tabular}{|c|c|c|c|c|c|c|c|c|c|}
\hline \multirow{4}{*}{$\begin{array}{l}\text { Odgovori } \\
\text { Answers }\end{array}$} & \multicolumn{6}{|c|}{ Razred/ Class } & \multirow{2}{*}{\multicolumn{2}{|c|}{ Ukupno/Total }} & \multirow{3}{*}{$\begin{array}{c}\text { Sveukupno/ } \\
\text { Total }\end{array}$} \\
\hline & \multicolumn{2}{|c|}{ Prvi /First } & \multicolumn{2}{|c|}{ Drugi/Second } & \multicolumn{2}{|c|}{ Treći/Third } & & & \\
\hline & q & $\hat{0}$ & 우 & $\hat{0}$ & q & $\hat{0}$ & q & $\hat{0}$ & \\
\hline & & & & & & & & & \\
\hline Plava/Blue & 6,7 & 6,8 & 17,7 & 16,7 & 11 & 13,6 & 12,1 & 11,3 & 11 \\
\hline Žuta/Yellow & 8,9 & 10,7 & 16,7 & 15,7 & 5,5 & 3,1 & 11,2 & 9,8 & 11 \\
\hline Zelena/Green & 84,4 & 79,6 & 61,5 & 58,8 & 77,8 & 81,8 & 73,4 & 71,1 & 74 \\
\hline Crvena/Red & 0 & 2,9 & 4,1 & 8,8 & 5,6 & 1,5 & 3,3 & 7,8 & 4 \\
\hline
\end{tabular}

早, djevojčice/girls; $\widehat{\partial}$, dječaci/boys 
Božica Lukšić i sur.: Očuvanje okoliša i praksa zbrinjavanja otpada prema mišljenju učenika mlađe školske dobi Grada Zagreba

Na 3. pitanje „Koje boje je spremnik za odlaganje papira?“ točno je odgovorilo $81 \%$ učenika (da je plave boje), $7 \%$ je odgovorilo da je žute boje, $8 \%$ da je zelene boje i $4 \%$ da je crvene boje (tablica 3.).

Tablica 3. Prikaz odgovora učenika na pitanje: „Koje boje je spremnik za odlaganje papira?“

Table 3 Students' answers to the question "What color is the container for papaer disposal?"

\begin{tabular}{|c|c|c|c|c|c|c|c|c|c|}
\hline \multirow{4}{*}{$\begin{array}{l}\text { Odgovori } \\
\text { Answers }\end{array}$} & \multicolumn{6}{|c|}{ Razred/Class } & \multirow{2}{*}{\multicolumn{2}{|c|}{ Ukupno/Total }} & \multirow{3}{*}{$\begin{array}{c}\text { Sveukupno/ } \\
\text { Total }\end{array}$} \\
\hline & \multicolumn{2}{|c|}{ Prvi/First } & \multicolumn{2}{|c|}{ Drugi/Second } & \multicolumn{2}{|c|}{ Treći/Third } & & & \\
\hline & 우 & $\widehat{0}$ & 우 & $\hat{0}$ & q & $\sigma^{\lambda}$ & q & $\sigma^{\lambda}$ & \\
\hline & & & & & & & & & \\
\hline Plava/Blue & 82,1 & 90,6 & 75,0 & 67,5 & 82,3 & 88,4 & 77,6 & 82,4 & 81 \\
\hline Žuta/Yellow & 9,0 & 5,7 & 5,2 & 10,0 & 7,8 & 5,8 & 7,1 & 7,0 & 7 \\
\hline Zelena/Green & $6,7 \%$ & 2,8 & 12,5 & 16,3 & 7,8 & 2,9 & 9,1 & 7,0 & 8 \\
\hline Crvena/Red & 2,2 & 0,9 & 7,3 & 6,2 & 2,1 & 2,9 & 6,2 & 3,6 & 4 \\
\hline
\end{tabular}

+ , djevojčice/girls; $\widehat{\jmath}$, dječaci/boys

Uspoređujući rezultate prikazane u tri tablice učenici 2. razreda su uvijek imali najmanji postotak točnih odgovora učenici 3. razreda pokazali su bolje znanje od učenika 2. razreda, dok su 1. razredi, što je iznenađujuće, pokazali najviše znanja u prethodna tri pitanja.

U današnjim obrazovnim sustavima, od devedesetih godina prošlog stoljeća do danas primjećuje se da su djevojčice uspješnije od dječaka u različitim područjima školskih postignuća pa i u onima u kojima su uobičajeno dječaci bili uspješniji (Burušić i Šerić, 2015.).

U istraživanju bioloških razlika u postignućima djevojčica i dječaka provedenom u 10 mjesta diljem SAD-a u kojem su sudjelovale 373 djevojčice i 364 dječaka tijekom šest godina, zaključeno je da djevojčice mentalno sazrijevaju ranije od dječaka (Marceau i sur., 2011). Boljem uspjehu djevojčica od dječaka u školi doprinose specifična obilježja (bolja samokontrola ili viša težnja za uspjehom) koja su kod djevojčica izraženija (Hicks i sur., 2008.). Suprotno, u istraživanju koje su proveli Nguyen i sur. (2005.) utvrđeno je da bolji uspjeh u školi postižu dječaci u odnosu na djevojčice radi bolje kontrole crta ličnosti (emocionalna stabilnost ili intelekt) što je djelovično u suglasju s rezultatima ovog istraživanja u kojem su dječaci u pojedinim segmentima ankete pokazali bolje znanje od djevojčica. 
Božica Lukšić i sur.: Očuvanje okoliša i praksa zbrinjavanja otpada prema mišljenju učenika mlađe školske dobi Grada Zagreba

Nadalje, u anketi se 4. pitanjem istraživalo odlažu li učenici papir i karton u plavi spremnik koji je namijenjen za odlaganje papira i kartona. U plavi spremnik papir i karton odlaže $68 \%$ učenika, $14 \%$ učenika ne odlaže papir i karton u plavi spremnik, a $18 \%$ učenika je navelo da papir i karton ponekad odlažu u plavi spremnik. Isto je u suglasju s ranijim istraživanjem (Stanić $\mathrm{i}$ Buzova, 2009.) u kojem je utvrđeno da se stari papir najviše ekološki ispravno zbrinjava te ga odlaže za recikliranje 69\% studenata Filozofskog fakulteta u Splitu.

U 1. pitanju je istraživano odlažu li učenici plastiku u žuti spremnik koji je namijenjen za odlaganje plastike. U žuti spremnik plastiku odlaže $72 \%$ učenika, da ne odlaže $11 \%$ učenika, a da ponekad odlaže odgovorilo je $17 \%$ učenika.

Prema istraživanju koje su proveli Stanić i Buzov (2009.) podatci o zbrinjavanju ambalažnog otpada pokazuju da studenti najviše zbrinjavaju plastiku (59\% studenata). Uspoređujući životne navike vezane za odlaganje otpada stanovništva Grada Splita (Stanić i sur. 2009.) i studenata (Stanić i Buzov, 2009.) zaključeno je da studenti manje recikliraju i više od ostalih građana odlažu ambalažu u smeće, što govori o njihovoj manjoj ekološkoj osjetljivosti.

U 6. pitanju je istraživano odlažu li učenici staklo u zeleni spremnik koji je namijenjen za odlaganje stakla. U zeleni spremnik staklo odlaže $72 \%$ učenika, ne odlaže $13 \%$ učenika, a $15 \%$ učenika je navelo da ponekad odlaže staklo u zeleni spremnik (tablica 4.).

Tablica 4. Prikaz odlaganja otpada u namjenske spremnike učenika prvih, drugih i trećih razreda osnovnih škola Grada Zagreba

Table 4 Presentation of waste disposal in dedicated containers by students of the first, second and third grades of primary schools in the City of Zagreb

\begin{tabular}{|l|c|c|c|}
\hline \multirow{2}{*}{\multicolumn{1}{|c|}{ Pitanje / Question }} & \multicolumn{3}{c|}{ Odgovor/Answer } \\
\cline { 2 - 4 } & $\mathrm{Da} / \mathrm{Yes}$ & Ne/No & Ponekad/Sometimes \\
\cline { 2 - 4 } & \multicolumn{3}{|c|}{$\%$} \\
\hline $\begin{array}{l}\text { Odlaganje papira i kartona u plavi spremnik } \\
\text { Dispose of paper and cardboard in a blue container }\end{array}$ & $\mathbf{6 8}$ & 14 & 18 \\
\hline $\begin{array}{l}\text { Odlaganje stakla u zeleni spremnik } \\
\text { Dispose of glass in a green container }\end{array}$ & $\mathbf{7 2}$ & 13 & 15 \\
\hline $\begin{array}{l}\text { Odlaganje plastike u žuti spremnik } \\
\text { Dispose of plastic in a yellow container }\end{array}$ & $\mathbf{7 2}$ & 11 & 17 \\
\hline
\end{tabular}


Božica Lukšić i sur.: Očuvanje okoliša i praksa zbrinjavanja otpada prema mišljenju učenika mlađe školske dobi Grada Zagreba

Premda svjesni potencijalnog ekološkog problema, studenti Filozofskog fakulteta u Splitu i ostali stanovnici Splita kao primarni razlog nerazvrstavanja otpada navode opterećenje, gubitak vremena i dodatne napore zbog tog složenog posla u svakodnevnom životu (Stanić i Buzov, 2009.). Prema podatcima Agencije za zaštitu okoliša RH u 2015. godini je ukupno sakupljeno $140441 \mathrm{t}$ ambalažnog otpada od čega je 55\% činio ambalažni otpad od papira i kartona, $25 \%$ staklena ambalaža, $18 \%$ ambalaža od plastike i $2 \%$ otpadna ambalaža od metala i drveta. Ukupno uporabljena količina ambalažnog otpada iznosila je 129869 t što je $92 \%$ od ukupno sakupljene količine. Stopa uporabe ukupnog ambalažnog otpada iznosila je $60 \%$, čime je ispunjen cilj uporabe koji iznosi $60 \%$. U odnosu na postavljene pojedinačne ciljeve recikliranja dostignuti su ciljevi za staklo (65\%), plastiku (46\%), i papir (89\%).

Prema izvješću o komunalnom otpadu Agencije za zaštitu okoliša RH iz 2017. godine, u 2016. godini je u RH ukupno proizvedeno $1679765 \mathrm{t}$ komunalnog otpada. Količina ambalažnog otpada iznosila je 167172 t, odnosno $39 \%$ od ukupne količine odvojeno sakupljenog komunalnog otpada. U ambalažnom otpadu oko $48 \%$ činila je ambalaža od papira i kartona, 25\% ambalaža od stakla, a ambalaža od plastike $20 \%$. Udio odvojeno sakupljenog komunalnog otpada (uključujući i mješoviti otpad poput glomaznog otpada, otpada od čišćenja ulica i dr.) u 2016. godini iznosio je $26 \%$. Riječ je o porastu od $2 \%$ u odnosu na 2015. godinu. Od ukupno proizvedene količine komunalnog otpada na odlagališta je upućeno $77 \%$ komunalnog otpada, a na oporabu $21 \%$ komunalnog otpada, dok je u 2010. godini na oporabu izravno upućeno 4\%.

U 7. pitanju je istraživano odlažu li djeca plastične boce u žuti spremnik ili ih nose na otkup. U žuti spremnik boce odlaže 55\% učenika, 39\% nosi boce na otkup, a $6 \%$ ih odlaže u miješani otpad.

Stanić i sur. (2009.) su zaključili da mlađi ispitanici, srednjeg obrazovanja i srednjih prihoda nisu skloni zbrinjavanju plastike, stakla i limenki te da tu ambalažu uglavnom bacaju u smeće. Razlog tomu navode nedostatak vremena te kompliciranost postupka odvajanja i povrata, dok su financijsku korist istaknuli u manjem broju. Stariji ispitanici, nižeg obrazovanja i nižih mjesečnih prihoda, najčešće vraćaju ambalažu u trgovine, jer su motivirani financijskim aspektom. Petina ispitanika, većinom mlađih, s visokim obrazovanjem i višim prihodom ambalažni otpad ostavljaju uz kontejnere te pokazuju socijalnu osjetljivost, dok je broj onih koji odlažu u ekokontejnere zanemariv. 
Božica Lukšić i sur.: Očuvanje okoliša i praksa zbrinjavanja otpada prema mišljenju učenika mlađe školske dobi Grada Zagreba

U 8. pitanju je istraživano zatvore li učenici prilikom pranja zubi vodu kako je ne bi bespotrebno trošili: $86 \%$ učenika je odgovorilo da ju zatvara, $7 \%$ da ne zatvara i 7\% da je ponekad zatvara. U 9. pitanju istraživano je da li učenici gase svjetlo nakon što izlaze iz prostorije na što je $85 \%$ učenika odgovorilo da gasi, $3 \%$ da ne gasi, a $12 \%$ da ponekad gasi svjetlo.

S vodom, jednako kao i sa strujom, potrebno je racionalno postupati i težiti smanjenju negativnog utjecaja na okoliš. Neodgovornim ponašanjem dolazi do iscrpljivanja prirodnih resursa, a i povećanja naknade za usluge korištenja vode i struje (NPEU, 2019).

U 10. pitanju je istraživano da li dok se igraju u parku, odlažu smeće u koš za smeće ili ga ostavljaju u prirodi pa je $99,2 \%$ učenika odgovorilo da smeće odlažu u koš, a preostalih $0,8 \%$ da ga ostavljaju u prirodi.

U 11. pitanju je istraživano na koji način učenici mlađe školske dobi osnovnih škola Grada Zagreba dolaze do škole. Ponuđeni odgovori su bili: automobilom, gradskim prijevozom (autobus / tramvaj) i pješice. Od anketiranih učenika, $44 \%$ učenika je odgovorilo da dolazi automobilom, $8 \%$ gradskim prijevozom i $48 \%$ da dolazi pješice.

\section{ZAKLJUČAK}

Iako čovjek poznaje načine vladanja prirodom, njenog iskorištavanja, kroćenja i očuvanja, sve češće smo svjedoci da ne vlada prirodom i neuspješno je ukroćuje (poplave, tornada, tsunamiji, suše, klimatske promjene) čemu doprinosi povećano onečišćenje okoliša i narušavanje ravnoteže ekosustava. Povećanje odgovornosti čovjeka prema prirodi uključuje obrazovanje djece o ekologiji, poticanje na ljubav prema prirodi, razmišljanja o očuvanju planeta Zemlja te tako poticanje buđenja ekološke svijesti i temeljnih načela očuvanja okoliša od najranije dobi.

Rezultati istraživanja ukazuju na dobro poznavanje načina zbrinjavanja otpada iz domaćinstava, spremnost na očuvanje okoliša i prirodnih resursa te postojanje dobrih navika u svakodnevnom životu koje pomažu očuvanju okoliša učenika od prvog do trećeg razreda osnovnih škola Grada Zagreba. Po broju točnih odgovora, učenici prvih razreda su jednako dobri kao i učenici drugih i trećih razreda što se može pripisati predškolskom ekološkom odgoju i obrazovanju. Izgradnja pozitivnog stava djece prema očuvanju okoliša treba biti zajednički i kontinuiran rad odgojno-obrazovnog sustava i kućnog odgoja. 
Božica Lukšić i sur.: Očuvanje okoliša i praksa zbrinjavanja otpada prema mišljenju učenika mlađe školske dobi Grada Zagreba

\section{LITERATURA:}

1. Barraz L. (1999.): Children's Drawings About the Environment, Environmental Education research. Vol. 5, No. 1.

2. Burušić, J. i Šerić, M. (2015.): Postignuća djevojčica i dječaka u školskom kontekstu: pregled mogućih objašnjenja utvrđenih razlika. Hrvatski časopis za odgoj i obrazovanje - Croatian Journal of Education (CJE). Vol.17, No. 4. 137-173.

3. Clifton, D. (2009.): Security and a Sustainable World. Journal of Sustainable Development, 2 (3): 3-17.

4. Davis, J. M. (1998.): Young children, environmental education and the future. Early Childhood Education Journal, Vol. 26, No. 2, 117-123.

5. Grodzinska- Jurczak, M. (2003.): The Relation Between Education, Knowledge and Action for Better Waste Management in Poland. Waste Management \& Research, 21(2): 2-18.

6. Hicks, B. M., Johnson, W., Iacono, W. G., McGue, M. (2008.): Moderating Effects of Personality on the Genetic and Environmental Influences of School Grades Helps to Explain Sex Differences in Scholastic Achievement. European Journal of Personality, 22, 247-268.

7. Hrvatska agencija za okoliš i prirodu (2017.): Izvješće o komunalnom otpadu za 2016. godinu. Dostupno na: http://www.haop.hr/hr/tematskapodrucja/otpad-i-registri-oneciscavanja/gospodarenje-otpadom/izvjesca (11.07.2018.)

8. Marceau, K., Ram, N., Houts, R.M., Grimm, K.J., \& Susman, E.J. (2011.): Individual Differences in Boys' and Girls' Timing and Tempo of Puberty: Modeling Development With Nonlinear Growth Models, Developmental Psychology, 47(5), 1389-1409.

9. NPEU, Nacionalni portal energetske učinkovitosti (2019.): Ušteda vode. Dostupno na: https://www.enu.hr/gradani/info-edu/usteda-vode/ (13.07.2018.)

10. [NN] Narodne novine (2013.): Zakon o održivom gospodarenju otpadom, 94/2013 (10.07.2018.)

11. Nguyen, N.T., Allen, L.C., Fraccastoro, K. (2005.): Personality Predicts Academic Performance: Exploring the moderating role of gender. Journal of Higher Education Policy and Management, 27(1), 105-116.

12. Novoselić, D., Bogut, I., Užarević, Z. (2013.): Zastupljenost ekoloških tema u udžbenicima predmeta Priroda i društvo u Republici Hrvatskoj i Federaciji Bosne i Hercegovine. Školski vjesnik: časopis za pedagogijsku teoriju i praksu. Vol.62 No.1, 129-147. 
Božica Lukšić i sur.: Očuvanje okoliša i praksa zbrinjavanja otpada prema mišljenju učenika mlađe školske dobi Grada Zagreba

13. Palmer, J.A. (1995.): Environmental Thinking in the Early Years: Understanding and Misunderstanding of Concepts Relating to Waste Management. Environmental Education Research. 1(1) 35-47.

14. Palmer, J., Birch, J. C. (2005.): Changing academic perspectives in environmental education research and practice: progress and promise. U: Johnson, E. A., Mappin, M. J. (ur.), Environmental Education and Advocacy, Changing perspectives of ecology and education (str. 114 - 137). Cambridge: Cambridge University Press.

15. Pavičić, V. (1993.): Uloga prirodoslovno-ekološkog odgoja i obrazovanja u razvoju gospodarstva i zaštite okoliša. Socijalna ekologija Zagreb. Vol. 2 No.2 (249-255).

16. Spajić-Vrkaš, V. (1993.): Globalni problemi svijeta i promjene odgoja i obrazovanja. U: Drandić, B. (ur.), Priručnik za ravnatelje odgojno-obrazovnih ustanova (str. 157- 177). Zagreb: Znamen.

17. Stanić, S., Buzov, I., Galov, M. (2009.): Prakse urbanog stanovništva u zbrinjavanju kućanskog otpada, Socijalna ekologija, 18(2):130-156.

18. Stanić, S., Buzov., I (2009.): Recikliranje i zbrinjavanje otpada - stavovi i aktivnosti studenata. God. Titius, god. 2, br. 2; 275-296.

19. Wells, N.M., Lekies, K.S. (2006.): Nature and the Life Course: Pathways from Childhood Nature Experiences to Adult Environmentalism. Children, Youth and Environments. Vol. 16, No. 1, Increasing Children's Freedom of Movement, and Other Papers, pp. 1-24.

Adresa autora - Author's address:

Božica Lukšić,

Krešimir Bošnjak, e-mail: kbosnjak@agr.hr

Ivana Čačić,

Marina Vranić, e-mail: mvranic@agr.hr

Sveučilište u Zagrebu Agronomski fakultet,

Zavod za specijalnu proizvodnju bilja,

pokušalište Centar za travnjaštvo,

Svetošimunska cesta 25, 10000 Zagreb, Hrvatska
Primljeno - Received:

28.02.2019. 
Božica Lukšić i sur.: Očuvanje okoliša i praksa zbrinjavanja otpada prema mišljenju učenika mlađe školske dobi Grada Zagreba 